\title{
The Relationship between Daily Maximum Temperature and Daily Maximum Ground Level Ozone Concentration
}

\author{
Ahmad Makmom Abdullah ${ }^{1 *}$, Marzuki Ismail², Fong Si Yuen², \\ Samsuri Abdullah², Rasheida E. Elhadi ${ }^{1}$ \\ ${ }^{1}$ Department of Environmental Sciences, Faculty of Environmental Studies, University Putra Malaysia, \\ 43400 UPM Serdang, Selangor \\ ${ }^{2}$ School of Marine Science and Environment, University Malaysia Terengganu, \\ 21030 Kuala Terengganu, Malaysia.
}

Received: 12 July 2016

Accepted: 26 September 2016

\begin{abstract}
Ground-level ozone is one of the dominant criteria pollutants that contribute to unhealthy days in ambient air measurements throughout Malaysia. In addition to VOCs and NOx, meteorological factors such as insolation and temperature influence the formation of ground-level ozone. For this reason, the relationship between daily maximum temperature and variation of ground-level ozone concentrations using 10 years of data (2000-10, excluding 2008) was scrutinized statistically at two stations representing urban and industrial areas in Terengganu State, Malaysia. We found that there is a positive linear correlation between maximum daily temperature and maximum daily ozone concentration with correlation coefficients of 0.684 and 0.605 for urban and industrial areas, respectively. Nevertheless, the long-term variation of daily maximum temperature and daily maximum ozone concentration for these two stations shows that the levels were higher in the industrial rather than the urban area. The results indicate that surrounding activities and temperature play vital roles in influencing ground-level ozone concentrations in Terengganu. Furthermore, ozone concentrations are highest for air masses characterized by dry, warm conditions during the southwest monsoon and are usually associated with the generation of haze episodes in the Malaysian Peninsula.
\end{abstract}

Keywords: ground-level ozone, daily maximum temperature, surrounding activities, Terengganu

\section{Introduction}

Ground-level ozone and particulate matter are the two overwhelmingly dominant criteria pollutants that

*e-mail: amakmom@upm.edu.my contribute to unhealthy days in ambient air measurements throughout Malaysia. Motor vehicles and industrial activities are the main sources of $\mathrm{O}_{3}$ precursors such as NOx and $\mathrm{CO}$. Thus the concentration of surface $\mathrm{O}_{3}$ is expected to be influenced by the amount of NOx, particularly from motor vehicles and the petrochemical industry [1-2]. In spite of the influence of motor vehicles and industrial emissions, 
the sea breeze appears to play an important role in the distribution of the precursors of $\mathrm{O}_{3}$ [3]. The combination of anthropogenic and biogenic $\mathrm{O}_{3}$ precursor species usually leads to high concentrations of $\mathrm{O}_{3}$ in the areas between highly populated urban centres and more forested or rural areas [2, 4-5]. Every day, millions of people around the world suffer from the harmful effects of ground-level ozone pollution, which worsens lung diseases such as asthma and can cause breathing difficulties even in healthy individuals [6-7]. Furthermore, it has also been identified as a harmful gas that affects crop yield and quality [8-9].

Ground-level ozone is a secondary pollutant formed in the air by the photochemical reaction of sunlight and nitrogen oxides (NOx), aided by a variety of volatile organic compounds (VOCs) that are photochemically reactive hydrocarbons. Power plants and motor vehicles are among the main source of ozone-forming pollutants and the ozone formation is also dependent on factors such as temperature and solar intensity [10-11]. Other than irradiation and windspeed, temperature is also found to play a significant role in influencing $\mathrm{O}_{3}$ concentrations. The effects of temperature were expressed as the total derivative $\left(\mathrm{d}\left[\mathrm{O}_{3}\right] / \mathrm{dT}\right)$ portrayed by no fewer than three components [12]:

$$
\begin{gathered}
\left(\mathrm{d}\left[\mathrm{O}_{3}\right] / \mathrm{dT}\right)= \\
\partial\left[\mathrm{O}_{3}\right] / \partial[\text { stagnation }] * \partial[\text { stagnation }] / \partial \mathrm{T}+ \\
\partial\left[\mathrm{O}_{3}\right] / \partial[\mathrm{PAN}]^{*} \partial[\mathrm{PAN}] / \partial \mathrm{T}+ \\
\partial\left[\mathrm{O}_{3}\right] / \partial[\text { isoprene }]^{*} \partial[\text { isoprene }] / \partial \mathrm{T}+
\end{gathered}
$$

...where (1) interaction of warm temperature with stagnant air masses can accumulate the local chemical precursors that form $\mathrm{O}_{3}$ in the planetary boundary layer [13]; (2) the high temperature condition increases the thermal decomposition of peroxyacetyl nitrate (PAN), a reservoir species of $\mathrm{NO}_{x}$ and $\mathrm{HO}_{x}$, thus decreasing the sequestration of these chemicals [14]; and (3) the temperature dependence of biogenic emission of isoprene, an abundant and highly reactive VOC precursor for $\mathrm{O}_{3}$ formation under high $\mathrm{NO}_{\mathrm{x}}$ conditions [15-16].

As Malaysia continues to develop vigorously, its advancements in the industrial and transportation sectors have increases emissions of $\mathrm{NO}_{\mathrm{x}}$ and VOC, which in turn increase ozone concentrations. Thus, this study is critical as most available studies are on the effect of wind speed and solar insulation toward ground-level ozone and only a few have looked at the relationship between temperature and ground-level ozone. This study attempts to correlate daily maximum temperature and daily maximum ozone concentration in two areas with different surrounding activities in Terengganu State, Malaysia. A positive correlation between temperature and ground-level ozone has been well established by previous studies [11, 17]. Furthermore, backward trajectories will also be performed to trace the preceding path of the air parcel before arriving at the study areas.

\section{Material and Methods}

Terengganu is located on the east coast of peninsular Malaysia with a total area of $13,035 \mathrm{~km}^{2}$. The total population of the state in 2010 was $1,015,776$. Two out of three air quality stations in Terengganu were selected for this study, i.e., SK ChabangTiga, Kuala Terengganu (S1), and SK Bukit Kuang, Kemaman (S2). These two stations are highly populated with total population for SK ChabangTiga, Kuala Terengganu, and SK Bukit Kuang, Kemaman of 337,553 and 166,750 , respectively, for 2010. Total traffic volume for this area is around 22,062 vehicle/day. SK Bukit Kuang, Kemaman is a developing Malaysian town located between the industrialized Kerti Petrochemical Industrial Area in the north and the industrial and urban Gabeng Industrial Area in the South. This area hosts dominant sources of ozone precursors related to industrial activities and road traffic. The locations of these stations are shown in Fig. 1.

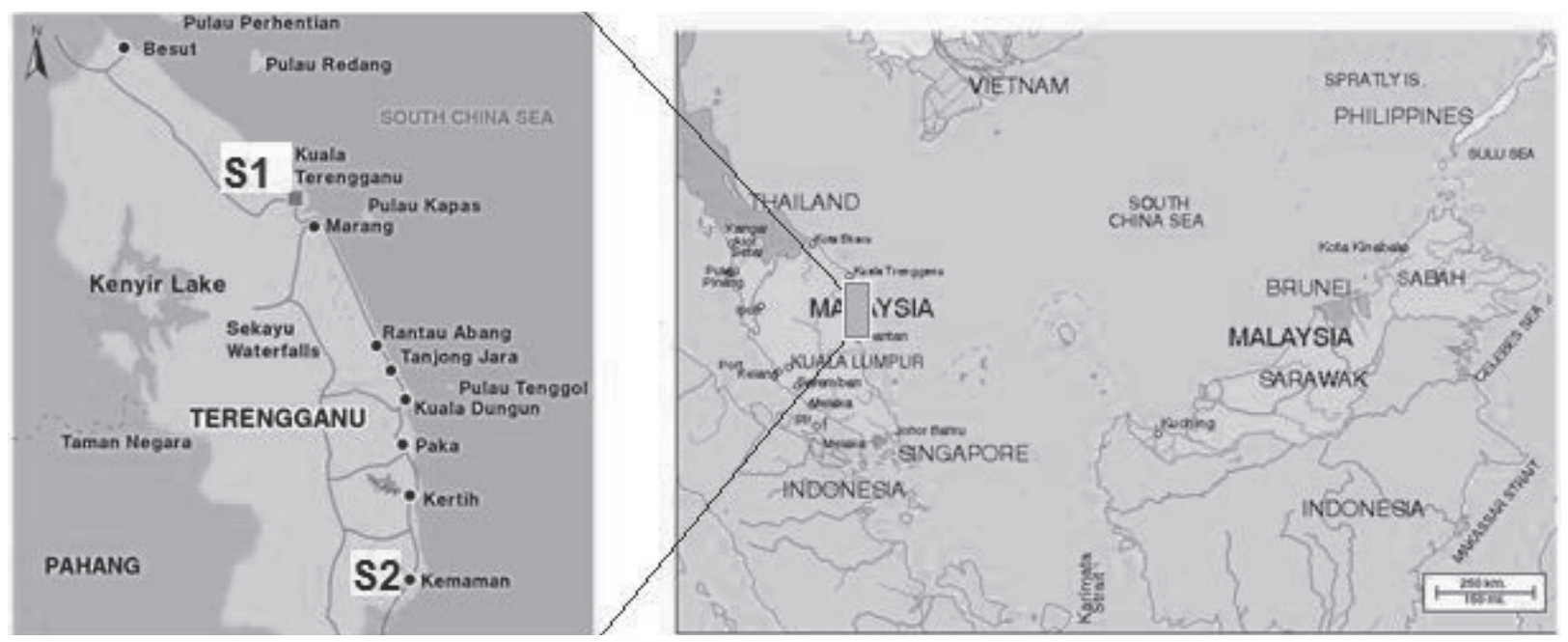

Fig. 1. Location of study area. 
Table 1. Location of air quality station, period of data collection and percentage of missing data.

\begin{tabular}{|c|c|c|c|c|c|c|}
\hline Station & Latitude & Longitude & Altitude $(\mathrm{m})^{\mathrm{a}}$ & Background & Sampling Duration & Missing Data \\
\hline SKChabangTiga(S1) & N05 $^{\circ} 18.487^{\prime \prime}$ & E103 $07.226^{\prime \prime}$ & $4.8 \pm$ & Urban & Jan 2000-Dec 2010 & $2 \%$ \\
\hline SK Bukit Kuang(S2) & N04 $^{\circ} 15.938^{\prime \prime}$ & E103 $25.941^{\prime \prime}$ & $10.0 \pm$ & Industrial & Jan 2000-Dec 2010 & $6 \%$ \\
\hline
\end{tabular}

a Altitude base on above sea level (ASL). $\quad$ b Duration of data used for analysis, excluding year 2008.

c Missing value based on data collection.

The details of the air quality stations are found in Table 1. S1 is located in an urban area whereas S2 is located in an industrial area. Both sampling stations were located inside the school compound.

Data used for analysis were obtained from the air quality monitoring stations in Terengganu State, which are managed by a private company, Alam Sekitar Sdn. Bhd. (ASMA) under commission by the Department of the Environment (DOE). The data used were the maximum daily temperatures and maximum daily surface ozone concentrations for the duration of 10 years, from January 2000 to December 2010 (excluding 2008 as the data for this year were incomplete). The data for daily maximum solar radiation of 2009 were also used in the analysis. The surface $\mathrm{O}_{3}$ concentrations at the ASMA air monitoring stations were measured using a Teledyne $\mathrm{O}_{3}$ Model 400A UV analyzer based on the Beer-Lambert law for measuring low ranges of $\mathrm{O}_{3}$ in ambient air. A $254 \mathrm{~nm}$ UV light signal was passed through the sample cell, where it was absorbed in proportion to the amount of ozone present. Every three seconds, a switching valve alternates measurements between the sample stream and a sample that has been scrubbed of ozone.

The daily maximum temperature and the daily maximum ozone concentration were determined from the hourly temperature and ozone data for the period 2000-10 (excluding 2008). The diurnal and annual cycles of the daily maximum temperature and the daily maximum ozone concentration variations studied boxplots of the assembled data. Statistical correlation was performed on the assembled data to obtain the correlation coefficients of daily maximum temperature and the daily maximum ozone concentration on the two stations. The missing values from the study period were omitted in the statistical computations.

The backward trajectories were calculated by using the Hybrid Single Particle Lagrangian Integrated Tra- jectory (HYSPLIT) Model. Back trajectory analysis is a commonly-used tool for understanding how short-term variability in surface ozone depends on transport to a given location [18]. This model has been introduced by the National Oceanographic and Atmospheric Administration (NOAA) at www.arl.noaa.gov/ready.html. The backward trajectories track the parcel of air reverse in time in hourly sequence for a specified period to determine the path where the air parcel passed by [19]. The trajectories for the two stations were developed for 120 hours and the model calculations were set at a height of $100 \mathrm{~m}$ above ground level on 1 January 2010 and 1 August 2010 to signify the northeastern and southwestern monsoons, respectively.

\section{Results and Discussion}

The summary of the data from the two sampling stations in Terengganu (SK ChabangTiga and SK Bukit Kuang) are shown in Table 2. The average daily maximum temperature recorded at $\mathrm{S} 1$ and $\mathrm{S} 2$ are $32.3^{\circ} \mathrm{C}$ $\left(23.3-39.5^{\circ} \mathrm{C}\right)$ and $32.8^{\circ} \mathrm{C}\left(22.0-39.7^{\circ} \mathrm{C}\right)$, respectively. These two values were found to have statistically significant difference as their $\mathrm{p}$-values were less than 0.05 . The average daily maximum ozone concentrations for S1 and S2 are 31.4 ppb (10.0-80.0 ppb) and $40.4 \mathrm{ppb}$ (12.0-89.0 ppb). The concentrations of daily maximum ozone at these two stations were also found to differ significantly $(\mathrm{p}<0.05)$.

Surrounding activities play an important role in affecting ambient air quality [19]. The concentration of the average daily maximum temperature and the daily maximum ozone concentration were higher in S2, which is the industrial area compared with $\mathrm{S} 1$, which is the urban area due to the fact that the precursors of ozone sources of ozone precursors - namely nitrogen oxides (NOx) and

Table 2. Overall summary on daily maximum temperature and the daily maximum ozone concentration.

\begin{tabular}{|c|c|c|c|c|c|c|c|c|}
\hline Parameters & Station & Avg.Time & Mean & Median & Std. Dev. & Min & Max & RMAQG* \\
\hline \multirow{2}{*}{ Temperature $\left({ }^{\circ} \mathrm{C}\right)$} & $\mathrm{S} 1$ & $1 \mathrm{~h}$ & 32.3 & 32.5 & 2.5 & 23.2 & 39.5 & - \\
\cline { 2 - 10 } & $\mathrm{S} 2$ & $1 \mathrm{~h}$ & 32.8 & 32.7 & 3.1 & 22.0 & 39.7 & \\
\hline \multirow{2}{*}{ Ozone $(\mathrm{ppb})$} & $\mathrm{S} 1$ & $1 \mathrm{~h}$ & 31.4 & 30.0 & 10.7 & 10.0 & 80.0 & 100 \\
\cline { 2 - 10 } & $\mathrm{S} 2$ & $1 \mathrm{~h}$ & 40.4 & 39.0 & 14.0 & 1.02 & 89.0 & \\
\hline
\end{tabular}

*RMAQG: Recommended Malaysian Air Quality Guidelines 
volatile organic compounds (VOC) - are produced from emissions of motor vehicles and industries. Additionally, these results concur with the research done locally in Malaysia [20-22] and globally [23], where the ozone concentration in a non-urban area was higher than an urban area due to ozone precursors that were gradually accumulated and transported to the downwind location. As it happens, S2 is downwind of S1. The average daily maximum ozone concentration for both stations is below the RMAQG.

Variations of the daily maximum temperature and the daily maximum ozone concentration are depicted in Fig. 2. The highest recorded daily maximum temperature for $\mathrm{S} 1$ and S2 happened in 2005 with values of $39.5^{\circ} \mathrm{C}$ and $39.7^{\circ} \mathrm{C}$. According to the [25], the 10 warmest years in the 134-year record have all occurred since 2000, with 2005 ranking as one of the warmest years on record. Additionally, like almost all the other countries of the world, Malaysia is also exposed to the risks of climate change and global warming. Over the last 40 years Malaysia has faced a rise in temperature of around $0.18^{\circ} \mathrm{C}$ [24-25]. Overall, the average daily maximum temperatures for both stations show increments, including S1 from $29.3^{\circ} \mathrm{C}$ in 2000 to $32.5^{\circ} \mathrm{C}$ in 2010 , and $\mathrm{S} 2$ from $31.7^{\circ} \mathrm{C}$ in 2000 to $35.7^{\circ} \mathrm{C}$ in 2010 .

The highest recorded daily maximum ozone concentration for S1 is $80.0 \mathrm{ppb} /$ year in 2004 and 2005, while for S2 it is $89.0 \mathrm{ppb}$ in 2003, 2007, and 2009. As for the lowest recorded daily maximum ozone concentration, $\mathrm{S} 1$ has a value of $2.0 \mathrm{ppb}$ in 2010 , while $\mathrm{S} 2$ is $4.0 \mathrm{ppb}$ in 2000. The average daily maximum ozone concentration for S1 shows some fluctuations, but overall the concentration shows a decrease of from $32.7 \mathrm{ppb}$ in 2000 to $26.0 \mathrm{ppb}$ in 2010. As for $\mathrm{S} 2$, the average daily maximum ozone shows inconstancy as the concentration increases from $37.8 \mathrm{ppm}$ in 2000 to a peak of $44 \mathrm{ppb}$ in 2007 descending to $39.8 \mathrm{ppb}$ in 2010. The decreasing concentrations of daily maximum ozone are the result of the reduction of usage of ozonedepleting substances [20], but the values were balanced by the increasing number of vehicles, thus creating the fluctuations of the trend.

The diurnal variations of daily maximum temperature and daily maximum ozone concentration for S1 and S2 are illustrated in Fig. 3. Overall, the highest daily maximum temperature and daily maximum ozone concentration for both stations was recorded in the hours between $1400 \mathrm{~h}$ and

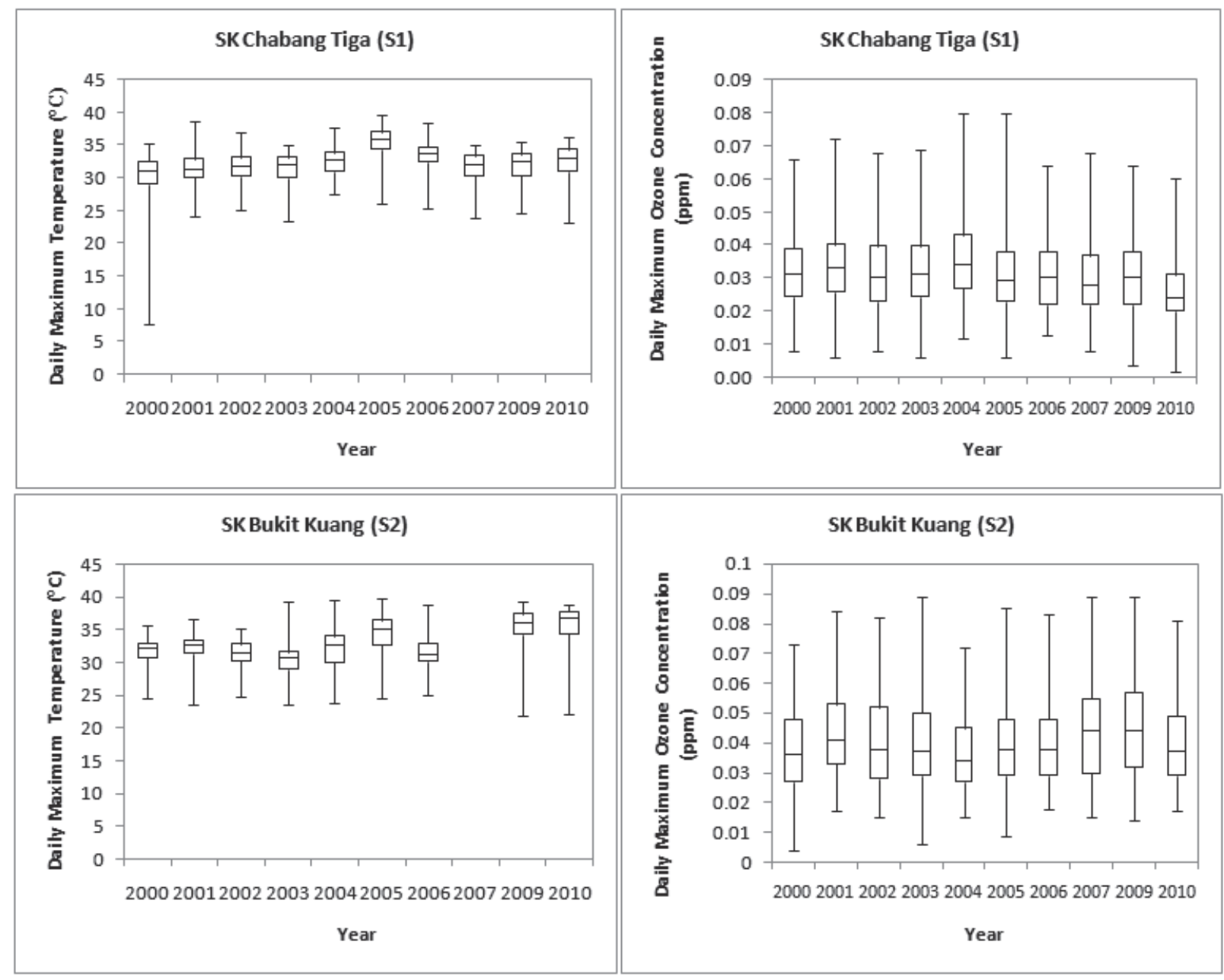

Fig. 2. The boxplot of daily maximum temperature and daily maximum ozone concentration trends for the period of 2000-2010*,*excluding year 2008 . 
Table 3. Correlation of the daily maximum temperature, daily maximum ozone concentration and daily maximum solar radiation of year 2009 of S2.

\begin{tabular}{|c|c|c|c|}
\hline & Ozone & UVB & Temperature \\
\hline Ozone & 1 & & \\
\hline UVB & 0.586489 & 1 & \\
\hline Temperature & 0.659047 & 0.888252 & 1 \\
\hline
\end{tabular}
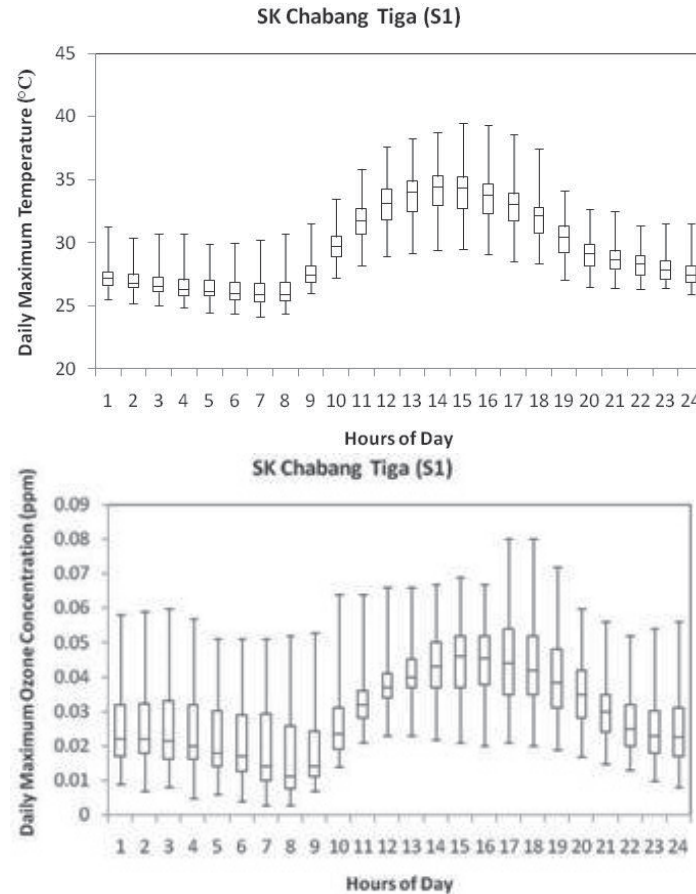

SK Bukit Kuang (S2)
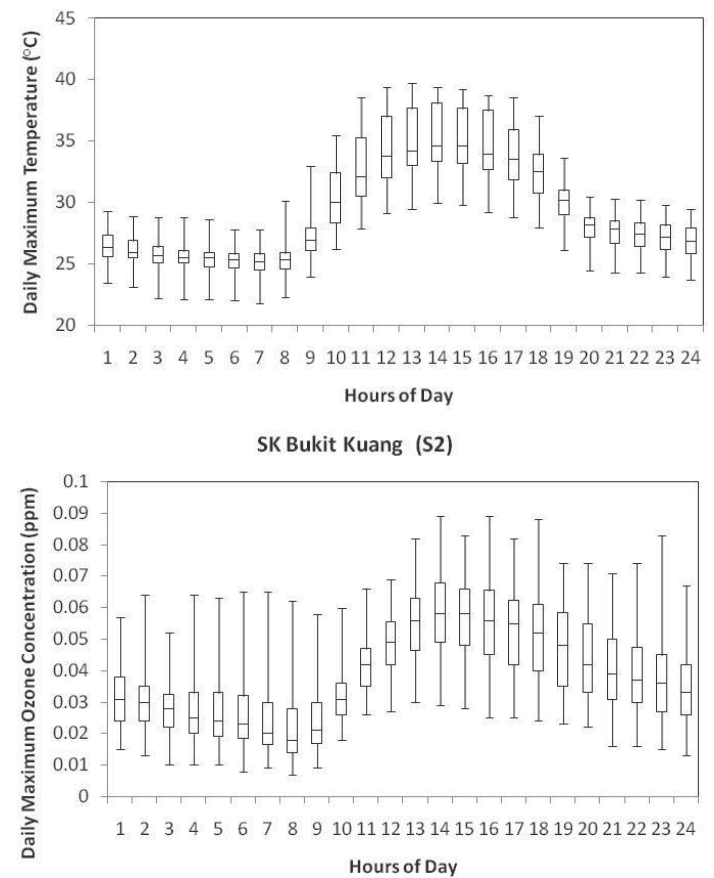

Fig. 3. Boxplot of the diurnal variations of daily maximum temperature and daily maximum ozone concentration for the period of 2000-2010*, *excluding year 2008 .
Plot of Fitted Model

Daily Max Ozone Conc $=-0.0384274+0.00260209 *$ Daily Max Temperature

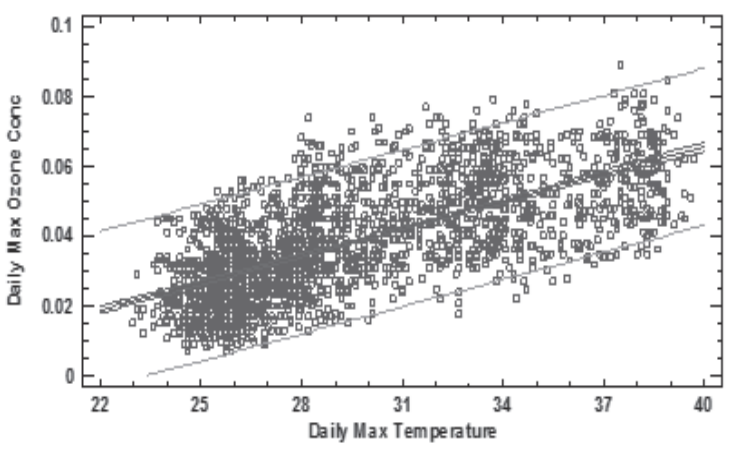

Plot of Fitted Model

Daily Max Ozone Conc $=-0.0450627+0.00256451^{*}$ Daily Max Temperature

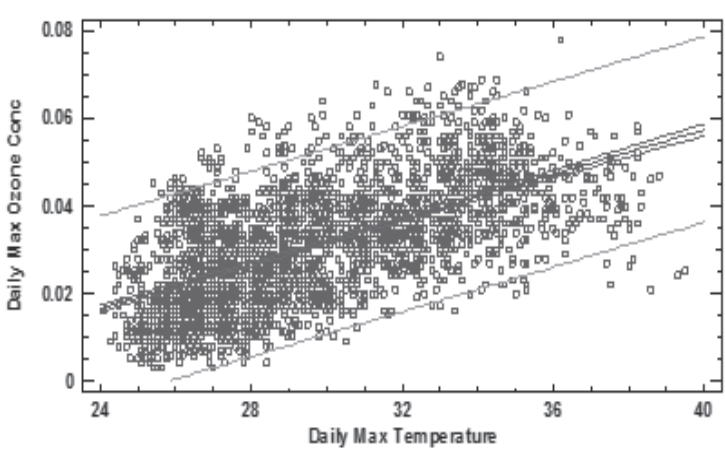

Fig. 4. Scatter plots of daily maximum temperature and daily maximum ozone concentration for the period of 2000-2010*, *excluding year 2008 .

1600h. The values for both daily maximum temperature and daily maximum ozone concentration rise steadily from $0900 \mathrm{~h}$ to the peak at $1400-1600 \mathrm{~h}$, and then decrease gradually.

The daily maximum temperature increases steadily from 0900 due to the increase of solar intensity during the peak sun hours, where the solar insulation that a particular location would receive if the sun were shining at its maximum value. The daily maximum temperature and the daily maximum ozone concentration tended to follow the intensity of solar radiation, causing higher levels during daytime and lower levels at night. The increase of solar intensity will cause the increase of temperature, which in turn escalates the ozone concentration.

The correlation of the daily maximum temperature, daily maximum ozone concentration, and daily maximum solar radiation of 2009 of S2 are shown in Table 3. Year 2009 of S2 was chosen due to the fact that it recorded the highest daily maximum ozone concentrations. The correlation between daily maximum temperature and daily maximum solar radiation is 0.888 . This shows that these two parameters are strongly correlated.

Linear correlations were established between ozone concentration values and the ambient air temperature $[17,26]$. The scatter plot for both stations (Fig. 4) shows that the results fit a linear model to describe the relationship between the daily maximum temperature and daily maximum ozone concentration for the period of 
2000-10 (excluding 2008). The correlation coefficient for S1 and S2 is 0.684 and 0.605 , respectively. The coefficient indicates that the relationship is moderately strong.

Ozone concentrations vary significantly across both air masses and trajectory clusters at both monitoring stations. Concentrations are highest for air masses characterized by dry, warm conditions between June and September

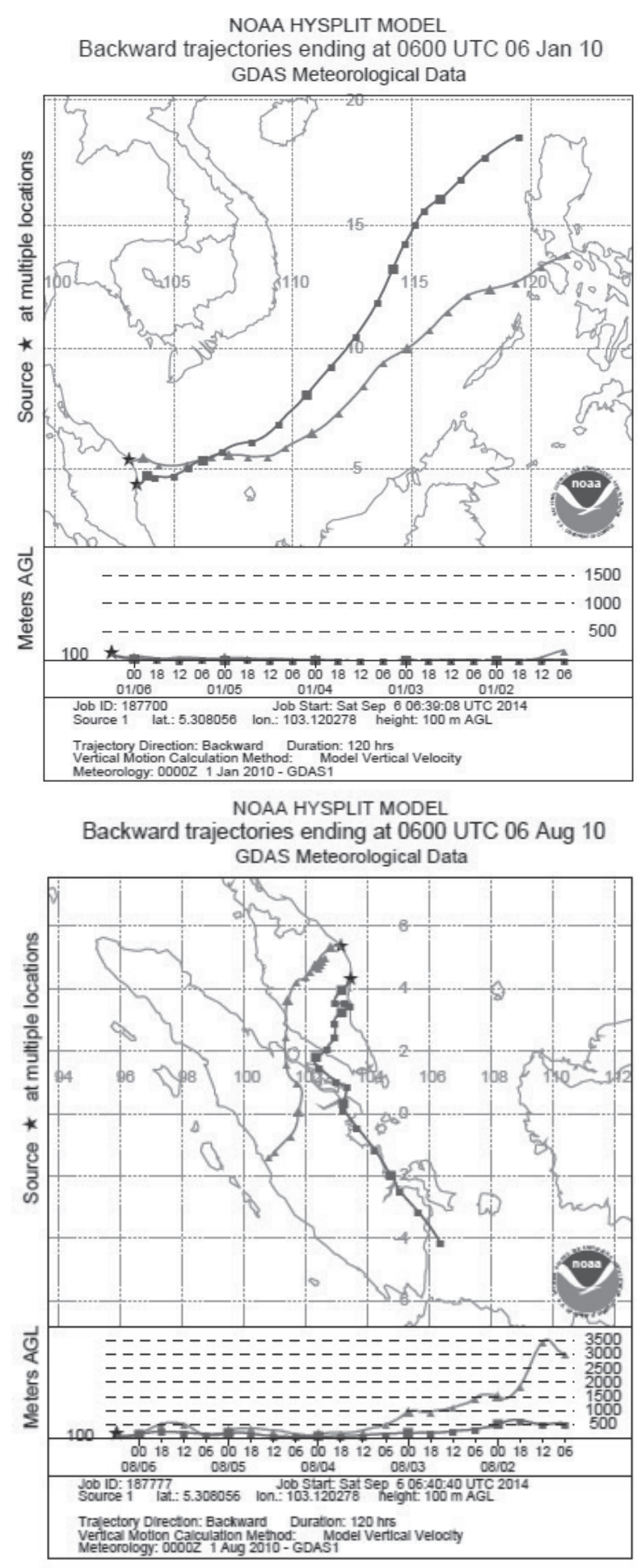

Fig. 5. Back trajectory analysis using HYSPLIT Model for north-east monsoon and southwest monsoon. each year, i.e., during the southwest monsoon and for air originating from Sumatra, Indonesia. Back trajectory analysis (Fig. 5) showed that the southwest monsoon wind from Sumatra can arrive at both monitoring stations within 84 hours and is frequently associated with the incidence of haze episodes in the Malaysian Peninsula as a result of biomass burning, which is the burning of peat soil and plant residue in Sumatra, Indonesia, and Indochina that releases vast quantities of smoke, consisting of a high quantity of pollutants into the atmosphere, which affects visibility and absorbs incident radiation [27-28]. Meanwhile, ozone concentrations are at the lowest during the northeastern monsoon, which occurs annually between November and March and is usually associated with the wet season. Back trajectory analysis showed that during this northeastern monsoon the air masses initiated from the South China Sea and the Philippines.

\section{Conclusion}

The results of the study showed that there is a positive linear relationship between daily maximum temperature and daily maximum ozone concentration in Terengganu. It proved that succeeding after factors such as wind speed and solar insulation, maximum temperature influences the ozone concentration. The study on long-term and diurnal variations of daily maximum temperature and daily maximum ozone concentration showed that significantly $(p<0.05)$, these two parameters are higher in the industrial area compared to the urban area. Thus it can be concluded that surrounding activities affect the temperature that plays an important role in influencing the ground-level ozone of the area. In addition, back trajectory analysis showed that ozone concentrations are highest during the southwest monsoon and are frequently associated with the prevalence of haze episodes in the Malaysian Peninsula.

\section{References}

1. AWANG N.R., ELBAYOUMI M., RAMLI N.A., YAHAYA A.S. Diurnal variations of ground-level ozone in three port cities in Malaysia. Air Quality, Atmosphere \& Health, 9 (1), 25, 2016.

2. LATIF M.T., DOMINICK D., AHAMAD F., AHAMAD N.S., KHAN M.F., JUNENG L. Seasonal and long term variations of surface ozone concentrations in Malaysian Borneo. Science of The Total Environment, 573, 494, 2016.

3. LATIF M.T., HUEY L.S., JUNENG L. Variations of surface ozone concentration across the Klang Valley, Malaysia. Atmospheric Environment, 61, 434, 2012.

4. BANAN N., LATIF M.T., JUNENG L., AHAMAD F. Characteristics of surface ozone concentrations at stations with different backgrounds in the Malaysian Peninsula. Aerosol and Air Quality Research, 13 (3), 1090, 2013.

5. STAVRAKOU T., MÜLLER J.-F., BAUWENS M., DE SMEDT I., VAN ROOZENDAEL M., GUENTHER A. Isoprene emissions over Asia 1979-2012: impact of climate and land-use changes. Atmospheric Chemistry and Physics, 14 (9), 4587, 2014. 
6. KINNEY P.L. Climate change, air quality, and human health. American journal of preventive medicine, 35 (5), 459, 2008.

7. SOUSA S., ALVIM-FERRAZ M., MARTINS F. Health effects of ozone focusing on childhood asthma: what is now known - a review from an epidemiological point of view. Chemosphere, 90 (7), 2051, 2013.

8. FENG Z., KOBAYASHI K. Assessing the impacts of current and future concentrations of surface ozone on crop yield with meta-analysis. Atmospheric Environment, 43 (8), 1510, 2009.

9. VAN DINGENEN R., DENTENER F.J., RAES F., KROL M.C., EMBERSON L., COFALA J. The global impact of ozone on agricultural crop yields under current and future air quality legislation. Atmospheric Environment, 43 (3), 604 2009.

10. FROST G., MCKEEN S., TRAINER M., RYERSON T., NEUMAN J., ROBERTS J. Effects of changing power plant NOx emissions on ozone in the eastern United States: Proof of concept. Journal of Geophysical Research: Atmospheres, 111 (D12), 2006.

11. JACOB D.J., WINNER D.A. Effect of climate change on air quality. Atmospheric environment, 43 (1), 51, 2009.

12. RASMUSSEN D., FIORE A., NAIK V., HOROWITZ L., MCGINNIS S., SCHULTZ M. Surface ozone-temperature relationships in the eastern US: A monthly climatology for evaluating chemistry-climate models. Atmospheric Environment, 47, 142, 2012.

13. JACOB D.J., LOGAN J.A., YEVICH R.M., GARDNER G.M., SPIVAKOVSKY C.M., WOFSY S.C. Simulation of summertime ozone over North America. Journal of Geophysical Research: Atmospheres, 98 (D8), 14797, 1993.

14. SILLMAN S., SAMSON P.J. Impact of temperature on oxidant photochemistry in urban, polluted rural and remote environments. Journal of Geophysical Research: Atmospheres, 100 (D6), 11497, 1995.

15. LAMB B., GUENTHER A., GAY D., WESTBERG H. A national inventory of biogenic hydrocarbon emissions. Atmospheric Environment (1967), 21 (8), 1695, 1987.

16. MELEUX F., SOLMON F., GIORGI F. Increase in summer European ozone amounts due to climate change. Atmospheric environment, 41 (35), 7577, 2007.

17. LIN C.-Y.C., JACOB D.J., FIORE A.M. Trends in exceedances of the ozone air quality standard in the continental United States, 1980-1998. Atmospheric Environment, 35 (19), 3217, 2001.

18. ROBICHAUD A., MÉNARD R. Multi-year objective analyses of warm season ground-level ozone and PM 2.5 over North America using real-time observations and Canadian operational air quality models. Atmospheric Chemistry and Physics, 14 (4), 1769, 2014.

19. Arizona Department of Environmental Quality (ADEQ), Arizona State Implementation Plan: Appendix C (WRAP Technical Support Summary: Back Trajectory Modeling). Retrieved from http:// www.azdeq.gov/environ/air/ haze/ download/haze308sip.pdf on December 29, 2014. 2011.

20. LU C., LIU Y. Effects of China's urban form on urban air quality. Urban Studies, p. 0042098015594080, 2015.

21. BANAN N., LATIF M.T., JUNENG L. An Assessment of Ozone Levels in Typical Urban Areas in the Malaysian Peninsular. in Proceedings of World Academy of Science, Engineering and Technology. World Academy of Science, Engineering and Technology (WASET), 2013.

22. AZMI S.Z., LATIF M.T., ISMAIL A.S., JUNENG L., JEMAIN A.A. Trend and status of air quality at three different monitoring stations in the Klang Valley, Malaysia. Air Quality, Atmosphere \& Health, 3 (1), 53, 2010.

23. AHAMAD F., LATIF M.T., TANG R., JUNENG L., DOMINICK D., JUAHIR H. Variation of surface ozone exceedance around Klang Valley, Malaysia. Atmospheric Research, 139, 116, 2014.

24. JEON W.-B., LEE S.-H., LEE H.-W., KIM H.-G. Process analysis of the impact of atmospheric recirculation on consecutive high-O 3 episodes over the Seoul Metropolitan Area in the Korean Peninsula. Atmospheric environment, 63, 213, 2012.

25. NOAA, National Climatic Data Center, State of the Climate: Global Analysis for Annual, published online December (2013). Retrieved on July 6, 2014 from http://www.ncdc. noaa.gov/sotc/global/2013/13. 2013.

26. TANGANG F., LIEW J.N., SALIMUN E., SEI K.M., LE L.J., MUHAMAD H. Climate change and variability over Malaysia. Sains Malaysiana, 41 (11), 1355, 2012.

27. ISMAIL M., IBRAHIM M.Z., IBRAHIM T.A. Time series analysis of surface ozone monitoring records in Kemaman, Malaysia. Sains Malaysiana, 40 (5), 411, 2011.

28. SANTAMOURIS M., KOLOKOTSA D.-D. Urban microclimates. Low Carbon Cities: Transforming Urban Systems, 282, 2014.

29. ABAS M.R., OROS D.R., SIMONEIT B.R. Biomass burning as the main source of organic aerosol particulate matter in Malaysia during haze episodes. Chemosphere, $\mathbf{5 5}$ (8), 1089, 2004.

30. JUNENG L., LATIF M.T., TANGANG F. Factors influencing the variations of PM10 aerosol dust in Klang Valley, Malaysia during the summer. Atmospheric Environment, 45 (26), 4370, 2011. 
